\title{
Why the Median-Priced Home Costs So Much
}

\author{
SCOTT E. HEIN and JAMES C. LAMB, JR.
}

NFLATION has caused many distortions that affect the affordability of housing, especially for firsttime buyers. Since 1965, the price of the medianpriced house in the United States has more than tripled. ${ }^{1}$ More important, however, the annual mortgage payment for a standard financing arrangement is almost seven times as large as before for the median-priced house. As a result, the median-income family is unlikely to qualify for and presumably would be reluctant to obtain conventional financing to buy the median-priced house today.

In 1965, the median before-tax family income was $\$ 7,610$, the new home mortgage rate averaged 5.81 percent, and the median sale price of a new onefamily house was $\$ 20,150$. With a 20 percent down payment and a 30-year mortgage to secure the balance, a homeowner would owe $\$ 1,136$ in annual interest and principal payment on the debt, approximately 14.9 percent of his income.

In 1980, by comparison, median before-tax income was approximately $\$ 21,500$, the new home mortgage rate for the year averaged 13.73 percent, and the median sale price of a new one-family house vaulted to $\$ 64,900$. The annual interest and principal charges on a 30-year mortgage for this home, again assuming a 20 percent down payment, would be $\$ 7,249$, or 33.7 percent of the median income (see table 1).

As evidenced by these numbers, the change in the cost of homeownership has been drastic. This article explains why this cost has risen so sharply: why the 1965 median-income family had to pay less than 15 percent of its annual income in mortgage payments on a median-priced house, while the 1980 median-income family must pay more than 33 per-

The median of a set of data is the number below and above which there are an equal number of observations.

\begin{tabular}{l} 
Table 1 \\
Comparison of Income and Mortgage \\
Payments for 1965 and 1980 \\
(current dollars) \\
\hline
\end{tabular}

Assumng 20 percent down payment.

cent. Two separate issues are considered: the increase in housing prices and the increase in the cost of financing a home purchase.

\section{THE TISE IN HOUSING PRICES}

From 1965 to 1980 , the prices of personal consump tion goods more than doubled, rising 131.8 percent. Since inflation is a sustained increase in the general level of prices, one would expect similar increases in housing prices. However, the prices of new housing for the same period rose an even higher 223.2 percent." Table 2 shows the annual rate of increase in new housing prices and personal consumption goods.

This indicates that individuals who owned homes over this period have experienced sizable capital gains. On this matter, see Patric H, Fendershott and Sheng Cheng Hu, "Inflation and the Benefits from Owner-Occupied Housing" (National Bureau of Economic Research, Working Paper No. 383, August 1979) for a discussion of the capital gains experienced by households, the present paper does not analyze the ramincations of these capital gains on the demand for housing. 


\section{Table 2}

\section{Annual Change in Housing Prices and the Personal Consumption Deflator ${ }^{1}$}

\begin{tabular}{|c|c|c|}
\hline Year & $\begin{array}{l}\text { Ohange in } \\
\text { housing prices }\end{array}$ & $\begin{array}{l}\text { Change } \\
\text { personal } \\
\text { consuntiot } \\
\text { defator }\end{array}$ \\
\hline 1965 & $29 \%$ & $1.7 \%$ \\
\hline 1966 & 35 & 29 \\
\hline 1967 & 3,6 & 24 \\
\hline 1968 & 5,6 & $4 r$ \\
\hline 1969 & 8,0 & 45 \\
\hline 1970 & 30 & 47 \\
\hline 1971 & 52 & 42 \\
\hline 1972 & 6,4 & 3.7 \\
\hline 1973 & 95 & 5,6 \\
\hline 1974 & 8,3 & 10,1 \\
\hline 1975 & 95 & 76 \\
\hline 1976 & 86 & 52 \\
\hline 1977 & 128 & 60 \\
\hline 1978 & 37 & 68 \\
\hline 1979 & 14.2 & 89 \\
\hline 1980 & 10,1 & 10,2 \\
\hline
\end{tabular}

1 ata on housmo pros are for new sales only

Only in 1970,1974 and 1980 was the annual rate of increase in housing prices less than that of personal consumption goods. Thus, while general inflation explains most of the increase in housing prices, it leaves unanswered the question why housing prices have risen faster than the general price level.

\section{Quality Changes}

One possible explanation for this phenomenon is that the quality of housing has risen over the past 15 years; thus, we are comparing the price of two dissimilar goods. Though this problem plagues all price index measures, it appears to be particularly important in the case of housing. The average new home is larger and has more amenities, such as central air conditioning and insulation. Still, economists generally believe that these quality increases are not substantial enough to fully explain the rapid relative price rise. ${ }^{3}$

\footnotetext{
"For example, Randall J. Pozdena, "Inflation Expectations and the Housing Market," Federal Reserve Bank of San Francisco Economic Review (Fall 1980), pp. 29-47, estimates that I5 percent of the increase in the average home sales price between 1970 and 1979 is explained by quality considerations.
}

\section{Demographic and Lifestyle Factors}

Additional factors that help explain the relative increase in hotsing prices are demographic changes since 1965. First, the adult population - the purchasers of homes - has grown rapidly in recent years. ${ }^{*}$ There appear to be two sources of this growth. One, individuals born in the post-World War II baby boom have moved into the homebuying age group. Two, the U.S. population now enjoys an increased longevity.

In addition, lifestyle changes apparently have increased the demand for shelter, at least partially affecting the demand for owner-occupied housing. For example, the proportion of unmarried adults has increased with the rise in the divorce rate and the postponement of marriage. These lifestyle changes have resulted in more and more single-person households. Today there often are two people demanding housing, where before there was one.

\section{Inflation and the Favorable Tax Treatment of Homeownership}

A third factor causing the relative rise of housing prices is the favorable treatment of homeownership by the U.S. tax structure. As inflation has accelerated, this treatment has become even more favorable. ${ }^{5}$ For example, an individual can deduct mortgage interest expenses from taxable income in determining his income tax. Thus, as nominal interest rates and mort gage rates rise with inflation, borrowers can decluct larger interest expenses, even if the real (inflation adjusted) cost of borrowing remains unchanged. In other words, the higher the anticipated future inflation, the cheaper it is to borrow under our tax system. $^{6}$ Since most people borrow to purchase a

"For a more detalled discussion, see Dan M. Bechter, "How Much For a New Howse in the Years Ahead? Some Insights From 1975-80' (Federal Reserve Bank of Kansas City, Research Working Paper 81-104)

"Anthony Downs "The Low (Real) Cost of Housinge" Across the Board (February 1981), pp. 51-55; James M. Poterba, "Inflation, Incone Taxes and Owher-Occupied Housing" (National Bureat of Economic Research. Working Paper No. 553, September 1980 ).

there is an important distinction between nominal and real interest rates. Nominal interest rates are market interest rates which state how many dollars the borrower will pay and the Lender will receive on a loan. Since inflation depreciates the value of a dollar in terms of its command over resources, nominal rates are bid up by antipipated inflation. Real interest rates are rates that have been adjusted for inflation. The expected real interest rate can be measured by subtracting the expected anmal rate of inflation from the nominal interest rate.

The favorable treatment given to bornowers comes from the fact that individuals can deduct nominal interest expenses 
house, this increasingly favorable treatment has increased the demand for the single-family dwelling.

This berefit becomes even more important as inflation pushes individuals into higher marginal income tax brackets (bracket creep). Bracket creep has increased the marginal tax rate for the median-income family from 17 percent in 1965 to 24 percent in 1980 . As individuals are pushed into higher marginal tax brackets, the value of deducting interest expenses increases. Thus, even if the interest expense on a loan or mortgage were unaffected by inflation, individuals would pay less after-tax dollars to borrow in 1980 than they did in 1965 . Since we have a progressive income tax structure, the increase in marginal tax rates has been even larger for family incomes greater than the median. In 1965, a family whose income was in the 80 th percentile (who earned more dollars than 80 percent of all other families) was in the 19 percent marginal tax bracket. In comparison, by 1930 this family was in the 37 percent marginal tax bracket. Thus, high-income families have experienced even greater reductions in the after-tax cost of borrowing as inflation has moved them into higher marginal tax brackets. ${ }^{7}$

In another benefit of our tax structure, capital gains realized from the sale of a home are not taxed if they are reinvested in another home. In addition, people over the age of 55 can now realize a tax-free, one-time capital gain of $\$ 100,000$ or less from the sale of their home. Consequently, some homeowners effectively pay no tax on capital gains from home ownership, substantially less than they would pay in taxes on capital gains from stocks or bonds.

An additional favorable tax consideration concerns housing as a form of investment. Consider an investor

from their incomes in determining taxable income. Compare two individuals - one in an inflationary environment with 10 percent inflation and the other in an enviromment with no inflation. Suppose the interest rates are 13 percent and 3 percent, respectively, so that the real rate is 3 percent in botl cases. Although the real cost of borrowing is the same for each individual, the alter-tax real cost is lower for the person in the inflationary enviromment since that individual's nomina? interest expense is much larger.

The point that the present tax structure favors borrowing has also been made in Lawrence $H$. Summers, "Inflation, the Stock Market and Owner Occupied Housing" (National Bureau of Economic Research, Working Paper No. 606, December 1980).

TSee Patric H. Hendershott, "Estimates of Imvestment Functions and Some Implications for Productivity Growth," in Laurence H. Meyer, ed, The Supply-Side Effects of Economic Poliey (St. Louis: Center for the Study of American Business and Federal Reserve Bank of St. Louis), pp. 149-65. who is contemplating two alternative purchases: a purchase either of $\$ 70,000$ in securities or a $\$ 70,000$ house. In the first case, the investor earns taxable interest income from the investment. In the latter, he receives no direct monetary remuneration, but he does obtain certain housing services referred to as "imputed rent"- the value of these services if the investor were renting the house. ${ }^{8}$ If the expected annual interest income equals the imputed rent (and if neither investment is appreciating in value), tax considerations would induce the investor to purchase the house rather than the securities, because the income earned from the house is untaxed.

Furthermore, inflation drives nominal interest rates up so that the interest income from securities increases (relative to interest income in noninflationary situations). This raises the tax burden on securities, making the investor worse off. Thus, a rise in the inflation rate increases the relative attractiveness of imputed income versus income from securities.

Finally, the U.S. tax structure is such that, during periods of high inflation, corporations are penalized with higher tax bills, while no such effect occurs on housing investments. Thus, individuals become wary of investing in corporate stocks. Corporations are affected because the depreciation of their assets is based on historic cost, and their inventories are valued by first-in-first-out (FIFO) inventory accounting. With respect to depreciation, present tax accounting practices do not write off capital expenses rapidly enough. In an inflationary environment, the dollar value of depreciation for a machine should represent both the physical deterioration of the machine, and the fact that it will take more clollars in the future to replace the machine or any of its parts. Present depreciation practices fail to recognize this latter element of depreciation and, as such, overstate corporate profits. With corporations paying more in taxes, the return to equity holders is reduced accordingly. A similar overstatement of profits results when corporations use FIFO inventory accounting. A number of studies have suggested that these factors have induced investors to divert money from the stock market into the housing market, where as noted above, more favorable tax treatment is available. ${ }^{\circ}$

$85 e$ Anthony M. Rufolo, "What's Ahead for Housing Prices?" Federal Reserve Bank of Philadelphia Business Review (Juty/ August 1980), pp. 9-15.

Patric H. Hendershott, "The Decline in Aggregate Share Values: Inflation and Taxation of the Returns From Equities and Owner"Ocoupied Housing" (National Bureau of Economic Research, Working Paper No, 370 , July 1970) and Summers, "Inflation, the Stock Market and Owner Occupied Housing." 
Many factors have increased the demand for residential housing over the last 15 years. ${ }^{10}$ It is important to recognize that part of this stimulus to demand comes from the favorable tax treatment of housing which has worked to increase the after-tax affordability of housing from an economic perspective; that is, the relative after-tax price of housing is being reduced by the interaction of inflation and the present tax structure. ${ }^{11}$ Looking at the ratio of mortgage pay ments to before-tax income, as many homebuyers and lending institutions do, fails to recognize this point.

\section{THE COST OF BORROWING}

As we have seen, housing prices have risen faster than other prices over the last 15 years. However, family incomes have also risen faster than inflation over this same period. In fact, family incomes nearly have kept up with housing prices. In 1965, the ratio of the median-priced house to the median family income was 2.6 ; in 1980 the ratio bad risen only to 3.0. Thus, ignoring tax considerations, the 1980 house would not appear to be substantially more expensive relative to income than it was in 1965 .

To make this point another way, consider what would result if the 1980 median-income family could purchase the 1980 median-priced house, at the 1965 mortgage rate. If this family bought a 1980 medianpriced home, but borrowed 80 percent of the purchase price at a mortgage rate equal to the 1965 average of 5.81 percent, its principal and interest payments would have been only 17.0 percent of the median family income. Thus, the 1980 median-income fanily could well afford the 1980 median-priced house, if only they could obtain a 5.81 percent mortgage rate. This hypothetical case is clearly unrealistic, but it does suggest that a major culprit in the 1980 affordability problem is today's high level of mortgage rates. At a mortgage rate of 13.73 percent, today's homebuyer would be paying more than 33 percent of his current income in terms of interest and principal alone.

\footnotetext{
${ }^{10}$ In addition, other factors have retarded the supply of housing. Bechter, "How Much For a New House" p. 13, sees government regulations "as being directly or indirectly responsible for holding back the rate of increase in the pace of homebuilding during the rising portion of the last housing cycle." In this light govemment policies have also increased the relative price of housing by imposing stringent zoning codes and subdivision regulations.

11This point has led Downs, "The Low (Real) Cost of Housing," to suggest that the United States is overinvesting in housing. Also, see Hendershott, "Estimates of Investment Functions."
}

But today's high level of mortgage rates, in and of itself, is not the problem. Though the mortgage rate was quite high in 1980 , it is unlikely that this rate has substantially reduced the long-run economic incentive to own a home. Quoted mortgage rates are nominal rates. Nominal rates alone, however, have little influence on an individual's purchasing or investment decisions. Both tax considerations and anticipated future inflation influence these decisions.

When the anticipated inflation rate and the favorable tax treatment given to housing are taken into account, homebuying is not nearly as adversely affected by high nominal mortgage rates as might first be thought. As we have seen, the ability to write off interest expenses reduces the true interest costs associated with purchasing a home. Last year, for example, a median-income family of four was in the 24 percent marginal tax bracket for U.S. income tax purposes. After deducting interest expenses from the purchase of a new home, the family's after-tax mortgage rate was reduced (at the margin) from the market rate of 13.73 percent to the net rate of 10.43 percent $[13.73 \times(1-0.24)]$. The 1965 median-income family, on the other hand, paid a 4.71 percent $[5.81 \times(1$. 0.19)] marginal after-tax mortgage rate.

Further, when inflation expectations are considered, this after-tax rate of 10.43 percent in 1980 may not be all that high. Nominal interest rates are high today, when compared to those in 1965 , because investors anticipate a higher future inflation rate than they anticipated in 1965. As such, they recognize that the dollars which will be paid back in the future will buy fewer goods, and they demand compensation accordingly. Borrowers, also anticipating inflation, recognize they will be paying back the loan with a depreciated currency and thus do not find high nominal interest rates prohibitive.

For example, take the 1965 median-income family who must pay 4,71 percent after taxes to borrow at the 1965 mortgage rate. Suppose this family anticipates that future inflation will be 2 percent per year. If this family borrows $\$ 100$ for a year, they would pay back, after tax deductibility is allowed, $\$ 104.71$ at the end of one year. Since they expect 2 percent inflation, however, they see the foregone $\$ 104.71$ as equivalent to giving up $\$ 102.66(\$ 104.71 / 1.02)$ in present dollars. Thus, the real after-tax interest rate is only 2.66 percent - this 1965 homebuyer expects to give up only $\$ 2.66$ worth of goods and services to borrow $\$ 100$.

How much inflation must today's homebuyer antici- 
pate to make them indifferent between the present arrangement and that of 1965 ? The after-tax mortgage rate for the 1980 median-income family is 10.43 perm cent. Thus, after tax deductions, the family will pay $\$ 110.43$ to borrow $\$ 100$ for one year at the 1980 mortgage rate. If the family anticipates inflation at 8 percent over the next year, they see the $\$ 110.43$ given up at the end of one year as equivalent to $\$ 102.25$ $(\$ 110.43 / 1.08)$ in 1980 dollars. The real after-tax rate is 2.25 percent. Thus, the 1980 median-income family expecting the future inflation rate to be 8 percent or more anticipates lower after-tax real borrowing costs than the 1965 median-income family that expected a future inflation rate of 2 percent.

If individuals expect inflation to continue at recent levels, the 10.43 percent after-tax rate the medianincome family must pay for a 13.73 percent mortgage represents a relatively small cost in terms of the real goods and services that must be given up. It is unlikely then that the recent high nominal mortgage rates alone have significantly discouraged home purchases. Thus, when both taxes and anticipated future inflation are taken into account, the after-tax real cost of the mortgage is apparently not unduly prohibitive.

\section{THE CONVENTIONAL MORTGAGE}

If, as has been argued, neither 1980 housing prices nor 1980 mortgage rates are too great a burden for prospective homeowners, what has caused the significant increase in the ratio of mortgage payments to income? The answer lies in restrictions resulting from conventional mortgage agreements.

Conventionally, mortgage debt is amortized over the repayment period, usually 25 to 30 years, so that the periodic payment is fixed, and both the principal and interest are paid off by the end of the loan. One of the main features of the conventional mortgage is that it fixes the periodic payments in dollar terms for the duration of the loan. This feature was useful in a noninflationary environment, but is it when future inflation is expected?

Consider two hypothetical cases in which a family with the median income in 1980 borrows $\$ 51,920$ to purchase the median-priced house. ${ }^{12}$ In the first case, suppose the family (and the rest of the public) anticipates no inflation in the future, expecting the prices of goods and services to remain essentially unchanged. The family realistically expects its income to rise, but this expectation is based on anticipated productivity gains, not inflation. As such, the increase in expected

\footnotetext{
${ }^{12}$ We will ignore all tax considerations in the following analysis.
}

future income implies an increased future command over goods and services. Assume the family expects their income to rise at an annual rate of 3 percent. Similarly, assume the family can borrow at a 3 percent rate.

In the second case, suppose the family (and the rest of the public) anticipates a steady 8 percent rate of inflation for 30 years. We assume that in every other way this family is similar to the first. Specifically, we assume that the family expects its income to grow in real (inflation-adjusted) terms at a 3 percent rate. This implies that the family expects their dollar income to increase at about an 11 percent rate -8 percent due to inflation, 3 percent due to real productivity gains. Table 3 lists the two respective dollar income streams that are anticipated in these two situations. While the expected income streams are quite different, each family expects its command over goods and services to be the same under each scenario. In addition, we will assume in this second case that the family expecting 8 percent inflation can borrow at an 11 percent rate, so that in real terms the cost of borrowing is 3 percent as it was in case one.

Thus, we are comparing a family in two different situations that are essentially identical when inflation is accounted for. Each family starts with the same dollar income and buys the same dollar-priced house. With the passing of every year, each family can buy 3 percent more goods and services than it could the previous year. In addition, the real cost of borrowing is the same in each case: to borrow a dollar today, each family promises to pay back enough money in one year to buy what $\$ 1.03$ buys today.

The two families should be equally happy. In real terms their situations are identical. But let us consider what would happen if each family were to obtain a conventional mortgage. In the first case, with the family expecting zero inflation and borrowing at a 3 percent rate, the annual mortgage payment turns out to be $\$ 2,627$. In the second case, the family expecting 8 percent inflation and borrowing at an 11 percent rate faces a $\$ 5,933$ annual mortgage payment. Over the full term of the mortgage, the two situations are identical. The significantly higher nominal payment in the second case is due to expected inflation. If, as we assume, inflation turns out to equal the 8 percent rate expected, the interest paid on the second debt over the full 30-year period will buy exactly the same amount of goods and services as in the no inflation case. Thus, in such a case the family is simply compensating the lender for the eroding value of money and is no worse off in a real sense. 


\section{Table 3}

Percent of Principal and Interest to Income With and Without Inflation

\begin{tabular}{|c|c|c|c|c|c|c|c|}
\hline \multicolumn{4}{|c|}{ No Inflation } & \multicolumn{4}{|c|}{$8 \%$ Inflation } \\
\hline Year & Payment & $\begin{array}{l}\text { Median } \\
\text { Incomo }\end{array}$ & $\begin{array}{l}\text { Payment as } \\
\text { apercent } \\
\text { of medlan } \\
\text { nncome }\end{array}$ & Payment & $\begin{array}{l}\text { Payment } \\
\text { adiusted } \\
\text { for } \\
\text { inflation }\end{array}$ & $\begin{array}{l}\text { Median } \\
\text { Income }\end{array}$ & $\begin{array}{l}\text { Payment as } \\
\text { a percent } \\
\text { of median } \\
\text { Income }\end{array}$ \\
\hline 1980 & $\$ 2,627$ & $\$ 21,500$ & $122 \%$ & $\$ 5,933$ & $\$ 5,933$ & $\$ 21,500$ & $27.6 \%$ \\
\hline 1981 & 2627 & 22,145 & 11.9 & 5,933 & 5,494 & 23,917 & 248 \\
\hline 1982 & 2627 & 22,809 & 115 & 5,933 & 5,087 & 26,604 & 22,3 \\
\hline 1983 & 2,627 & 23,494 & 11,2 & 5,933 & 4710 & 29,596 & 200 \\
\hline 1984 & 2627 & 24,198 & 109 & 5,933 & 4,361 & 32,921 & 180 \\
\hline 1985 & 2,627 & 24,924 & 10.5 & 5,933 & 4,038 & 36,622 & 162 \\
\hline 1986 & 2,627 & 25,672 & 102 & 5,933 & 3,739 & 40,738 & 14.6 \\
\hline 1987 & 2627 & 26,442 & 9.9 & 5,933 & 3,462 & 45,317 & 131 \\
\hline 1988 & 2,627 & 27,235 & 9.6 & 5,933 & 3,205 & 50,410 & 118 \\
\hline 1989 & 2,627 & 28,052 & 9.4 & 5,933 & 2,968 & 56,076 & 10.6 \\
\hline 1990 & 2,627 & 28,894 & 91 & 5,933 & 2,748 & 62,380 & 9.5 \\
\hline 1991 & 2,627 & 29761 & 8.8 & 5,933 & 2,545 & 69,392 & 8.5 \\
\hline 1992 & 2,627 & 30,654 & 8,6 & 5,933 & 2356 & 77,192 & 7.7 \\
\hline 1993 & $2 ; 627$ & 31,573 & 8.3 & 5,933 & 2,182 & 85,867 & 69 \\
\hline 1994 & 2,267 & 32,520 & 81 & 5,933 & 2,020 & 95518 & 6.2 \\
\hline 1995 & 2,627 & 33,496 & 78 & 5,933 & 1,870 & 106,255 & 5.6 \\
\hline 1996 & 2,627 & 34,501 & 76 & 5,933 & 1732 & 118,198 & 5.0 \\
\hline 1997 & 2,627 & 35,536 & 7,4 & 5,933 & 1,604 & 131,484 & 4.5 \\
\hline 1998 & 2,627 & 36,602 & 71 & 5933 & 1,485 & 142,262 & 4. \\
\hline 1999 & 2,627 & 37,700 & 7.0 & 5,933 & 1,375 & 162,702 & 3.7 \\
\hline 2000 & 2,627 & 38,831 & 6.8 & 5,933 & 1,273 & 180,990 & 33 \\
\hline 2001 & 2,627 & 39,996 & 6.6 & 5,933 & 1,179 & 201,333 & 30 \\
\hline 2002 & 2,627 & 41,196 & 64 & 5,933 & 1,091 & 223,960 & 2,7 \\
\hline 2003 & 2,627 & 42,431 & 6.2 & 5,933 & 1,010 & 249,132 & 2.4 \\
\hline 2004 & 2,627 & 43,704 & 60 & 5,933 & 936 & 277,135 & 2.1 \\
\hline 2005 & 2,627 & 45,015 & 58 & 5,933 & 866 & 308,289 & 19 \\
\hline 2006 & 2,627 & 46,366 & 5.7 & 5,933 & 802 & 342,939 & 1.7 \\
\hline 2007 & 2,627 & 47,757 & 5.5 & 5,933 & 743 & 381,486 & 16 \\
\hline 2008 & 2,627 & 49,189 & 5,3 & 5933 & 688 & 424,359 & 1.4 \\
\hline 2009 & 2,627 & 50,665 & 5.2 & 5,933 & 637 & 472,060 & 13 \\
\hline
\end{tabular}

This, however, is a long-run perspective. In the short run (less than the full term of the mortgage), as table 3 indicates, the two families are treated very differently. Specifically, the proportion of income spent on the mortgage when inflation is expected to be 8 percent is much larger in the early years of the mortgage. For example, in the first year the mortgage payment is 27.6 percent of the family income with 8 percent expected inflation, as opposed to 12.2 percent of the family income in the zero anticipated inflation case.

The explanation for this is simple enough. When everyone anticipates inflation, the borrower must not only repay the principal and interest, but must also compensate the lender for the eroding value of money. 
Since, under the conventional mortgage, the periodic payment is fixed in nominal terms, the borrower must compensate the lender early in the repayment period for inflation expected to occur many years down the road. However, the ratio of mortgage payment to family income falls quite rapidly as the second fam ily's income increases because of productivity gains and inflation, so that the very high ratio early in the mortgage is counter-balanced by a lower ratio later on.

The conventional mortgage thus treats the homebuyer very differently depending on anticipated inflation. In a noninflationary environment, the family income is expected to be relatively stable in dollar terms, and the mortgage payment plan is in complete agreement with such an expectation. However, in an inflationary environment the family expects its income to rise with inflation; the fixed dollar mortgage payment fails to take such an expectation into account. Thus, while nominal interest rates clearly reflect expectations of future inflation and require compensation accordingly, the payment schedule for a conventional mortgage does not reflect such expectations.

\section{THE MORTGAGE PAYMENT.NCOME RATIO: LOAN CRITERION}

This example indicates quite pointedly how allowing for a maximum ratio on the mortgage payment to family income is a dubious rule for the lender to follow in determining whether or not to make a loan under conventional arrangements. The two families are in exactly the same situation in real terms. The current house prices are the same. The expected real income streams are the same. And the expected real interest rates are the same. Therefore, if the family in the noninflationary environment can buy the house, then the family in the inflationary environment should also be able to buy the same house.

Solely considering the ratio of the nominal mortgage payment to income in the first year of the mortgage would suggest that the family expecting 8 percent inflation is less able to afford the house than the family expecting no inflation. However, this problem is a function of the interaction of anticipated inflation and the conventional mortgage; it is unrelated to whether or not the family can ultimately pay off the loan. Surely if the family could "afford" the home in the case of zero inflation, they could "afford" it in the case of 8 percent inflation. In this light, recent increases in the acceptable mortgage payment to family income ratio are not seen as a major problem for the long-run solvency of mortgage lenders, and in fact is a natural response to the interaction of inflation and the conventional mortgage.

\section{The Real Montgage Expenses}

Table 3 further shows that the family in the inflationary situation pays a substantially larger inftationadjusted mortgage payment in the early years of the mortgage than the family in the non-inflationary case. In our example, the real payments (in terms of actual command over goods and services) are higher for the family in the inflationary environment for the first 11 years and lower thereafter. Thus, the early payments are high, not only relative to the family income, but in real terms also.

In real terms, the family in the inflationary environment is saving more in the early part of the mortgage than the family expecting no inflation. Relative to the family expecting no inflation, the family anticipating 8 percent inflation is postponing consumption in the early years of the mortgage so it can make the high nominal payments. This postponed consumption early in the life of the mortgage is, of course, offset by lower real payments later on.

It is important to recognize that this savings decision was dictated by the interaction of inflation and the conventional mortgage. It may not be a choice that the family would prefer. For example, our family expecting 8 percent inflation may not like the idea of spending 27.6 percent of their 1980 income on mortgage payments. But, to the extent that only fixed nominal payment plans are being offered, their choice becomes either to accept this savings schedule or to forego buying the home. In this light, it is entirely likely that we could see a reduced demand for housing in periods of high anticipated inflation, as a result of the pattern of real costs imposed by the conventional mortgage. Families and individuals may forego buying homes in inflationary periods, not because housing is no longer a worthwhile long-term investment, but because of the disproportionate real mortgage payments forced on them in early years by the conventional fixed-payment mortgage.

\section{THE CONVENTIONAL MORTGAGE AND EXPECTED INELATION}

Our example has shown that in the face of expected inflation the conventional mortgage acts to frontend load the mortgage payments both in real terms and relative to a family's current income. Moreover, as expected inflation accelerates, the front-end loading problem becomes more severe. The larger the 
Table 4

Percent of Principal and Interest to Income Under Different Rates of Inflation

\begin{tabular}{|c|c|c|c|c|c|c|c|c|}
\hline \multirow[b]{2}{*}{ Year: } & \multicolumn{4}{|c|}{$8 \%$ frtation } & \multicolumn{4}{|c|}{$13 \%$ Inflation } \\
\hline & Payment & $\begin{array}{l}\text { Payment } \\
\text { adjusted } \\
\text { for intlation }\end{array}$ & $\begin{array}{l}\text { Modian } \\
\text { income }\end{array}$ & $\begin{array}{l}\text { Paymentas } \\
\text { aperoent } \\
\text { of median } \\
\text { moome }\end{array}$ & Payment & $\begin{array}{l}\text { Payment } \\
\text { adjusted } \\
\text { for inflation }\end{array}$ & $\begin{array}{l}\text { Median } \\
\text { income }\end{array}$ & $\begin{array}{l}\text { Payment as } \\
\text { apercent } \\
\text { of median } \\
\text { Income }\end{array}$ \\
\hline 1980 & $\$ 5,933$ & $\$ 5933$ & $\$ 21500$ & $27,6 \%$ & $\$ 6,892$ & $\$ 6,892$ & $\$ 21,500$ & $321 \%$ \\
\hline 1981 & 5,933 & 5,494 & $\begin{array}{r}23,917 \\
\end{array}$ & 248 & 6,892 & 6,099 & 25,024 & 275 \\
\hline 1982 & 5,933 & 5,087 & 26,604 & 223 & 6,892 & 5397 & 29,125 & 23,7 \\
\hline 1983 & 5,933 & 4,710 & 29,596 & 200 & 6,892 & 477 & 33,899 & 20.3 \\
\hline 1984 & 5,933 & 4361 & 32,921 & 180 & 6,892 & 4,227 & 39,454 & 17.5 \\
\hline 1985 & 5,933 & 4038 & 36,622 & 16.2 & 6,892 & 3741 & 45921 & 150 \\
\hline 1986 & 5,933 & 3,39 & 40,738 & 14.6 & 6,892 & 3310 & 53,448 & 129 \\
\hline 1987 & 5933 & 3,462 & 45,317 & 131 & 6,892 & 2930 & 62,208 & 111 \\
\hline 1988 & 5933 & 3,205 & 50,410 & 118 & 6,892 & 2,592 & 72,403 & 9.5 \\
\hline 1989 & 5,933 & 2968 & 56,076 & 10.6 & 6,892 & 2,294 & 84,269 & 8.2 \\
\hline 1990 & 5,933 & 278 & 62,380 & 9.5 & 6,892 & 2,030 & 98,082 & 70 \\
\hline 1991 & 5,933 & 2,545 & 69,392 & 8.5 & 6892 & 1,797 & 114,59 & 6.0 \\
\hline 1992 & 5933 & 2,356 & 77,192 & 77 & 6,892 & 1,590 & 131,570 & 5.2 \\
\hline 1993 & 5,933 & 2,182 & 85867 & 6.9 & 6,892 & 1,407 & 154,645 & 4.5 \\
\hline 1994 & 5,933 & 2,020 & 95,518 & 62 & 6,892 & 1245 & 179,990 & 3.8 \\
\hline 1995 & 5933 & 1,870 & 106255 & 56 & 6,892 & 1,102 & 209,493 & 3.3 \\
\hline 1996 & 5933 & 1732 & 118,198 & 50 & 6,892 & 975 & 243,830 & 28 \\
\hline 1997 & 5,933 & 1,604 & 131,484 & 45 & 6892 & 803 & 283793 & 2.4 \\
\hline 1998 & 5,933 & 1,485 & 142,262 & 41 & 6,892 & 764 & 330,306 & 21 \\
\hline 1999 & 5,933 & 1,375 & 162,702 & 37 & $6 ; 892$ & 676 & 384443 & 1.8 \\
\hline 2000 & 5933 & 1273 & 180,990 & 3.3 & 6,892 & 598 & 447,453 & 1.5 \\
\hline 2001 & 5,933 & 1,779 & 201,333 & 30 & 6,892 & 528 & 520,791 & 1.3 \\
\hline 2002 & 5933 & 1,091 & 223,969 & 27 & 6,892 & 468 & 606,151 & 11 \\
\hline 2003 & 5933 & 1,010 & 249,132 & 2.4 & 6,892 & 415 & 705,484 & 10 \\
\hline 2004 & 5,933 & 936 & 277,135 & 21 & 6,892 & 367 & $82 / 115$ & 08 \\
\hline 2005 & 5,933 & 866 & 308,289 & 19 & 6,892 & 325 & 955,693 & 07 \\
\hline 2006 & 5933 & 802 & 342,939 & 17 & 6,892 & 287 & $1,112,344$ & 0,6 \\
\hline 2007 & 5,933 & 743 & 381,486 & 16 & 6,892 & 254 & $1,294,657$ & 0.5 \\
\hline 2008 & 5,933 & 688 & 424,359 & 1.4 & 6,892 & 225 & $1,506,831$ & 0.5 \\
\hline 2009 & 5,933 & 637 & 472,060 & 13 & 6,802 & 190 & $1,753,812$ & 0.4 \\
\hline
\end{tabular}

expected rate of inflation, the higher the nominal mortgage rate and the higher the first-year conventional mortgage payment - both in real terms and relative to family income. Table 4 shows this for a case in which inflation accelerates from 8 percent to 13 percent. ${ }^{13}$

${ }^{15}$ At 13 percent inflation, the family's mortgage payment in 1980 is 32.1 percent of their 1980 income. If inflation was expected to be 40 percent or more, the family's mortgage payment would have exceeded their income.
This feature explains in large part why we had no "affordability" problem from 1976 through $1978 .{ }^{14}$

\footnotetext{
14There is cursory evidence that the front-end loading problem was evident in 1974. That year saw a sharp acceleration in both inflation and nominal interest rates. The FHA mortgage rate averaged 9.55 percent that year. As such, conditions were conctucive for the imposition of significant real mortgage payments early in the loan. Along these lines it is appropriate to note that 1974 was one of only two years from 1965 to $1980 \mathrm{in}$ which housing prices did not rise as rapidly as consumption goods.
} 
Over this period, both inflation and nominal interest rates were fairly low - suggesting relatively low expected inflation. For example, the FHA mortgage rate was below 10 percent from 1976 through 1978. Beginning in 1979, however, inflation and nominal interest rates rose sharply. Since the early part of 1979 , the front-end loading problem has likely become an important one for homebuyers, especially first-time

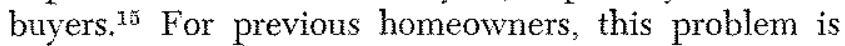
not as severe since they have realized significant capital gains from homeownership which can offset the front-end loading problem.

\section{SUMMARY AND CONCLUSTON}

A family with the 1980 median income must pay over 33 percent of their income to buy the 1980 median-priced house. In comparison, the 1965 medianincome family paid less than 15 percent of their income to buy the 1965 median-priced house. To some

15There is an alternative motgage arrangement that can be implemented to avoid this problem. For a discussion of such a mortgage, see Donald Lessard and Franco Modigliani, "In" flation and the Housing Market: Problem and Potential Soltutions," in Donald Lessard and Franco Modigliani, eds., New Hortgage Designs for Stable Housing in an Inflationary Environment (Procedings of a Conference Sponsored by the Federal Reserve Bank of Boston), pp. 13-45; and Henry $F$. Cassidy, "Price-Eevel Adjusted Mortgages (PLAMs): A Comparison with other Home Mortgage Instriments" (Federal Home Loan Bark Board, Working Paper No. 90, Jankary 1981).

Note, however, that the variable or nenegotiable mortgage rate arrangenents will not resolve the current cash-How problems for frst-time buyers. extent, this drastic change is due to the fact that housing prices have risen faster than inflation, spurred on by demographic factors and the preferential tax treatment of housing which has accelerated with infla tion. Family incomes, however, have to a large extent kept up with housing prices, so this phenomenon is not as crucial as may first appear.

The main culprit in causing the significant increase in the proportion of income a new buyer must pay to purchase a house is the combination of the expectation of higher future inflation and the conventional mortgage. Expected inflation requires that lenders be compensated for the expected deterioration in the purchasing power of money. Moreover, the conventional mortgage requires that payments, including those due to future inflationary effects on the value of money, be spread evenly over the duration of the mortgage so that dollar payments are constant. As such, today's conventional mortgage imposes a significant cash-flow problem for the homebuyer, especially the first-time buyer.

It is thus likely that many prospective new homebuyers recently have postponed home purchases or have bought a lower-priced home than they originally desired, either because of the significant real costs of the mortgage in the early years, or because of the limitation on mortgage debt to income imposed by credit institutions. In this regard, any actions taken to reduce inflation will benefit the long-term future of the housing industry.

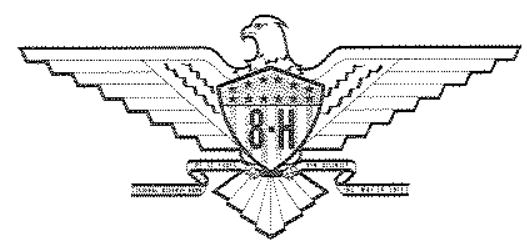

